Jurnal Riset Manajemen Sains Indonesia (JRMSI) | Vol 11, No. 2, 2020 e-ISSN: 2301-8313

http://doi.org/10.21009/JRMSI

DOI: doi.org/10.21009/JRMSI.011.2.010

\title{
PENGARUH RELIGIUSITAS, PREFERENSI RISIKO, DAN LOCUS OF CONTROL TERHADAP PERILAKU KEUANGAN DAN DAMPAKNYA TERHADAP PERSONAL FINANCIAL DISTRESS PADA PEKERJA MUDA DI DKI JAKARTA
}

\author{
Gatot Nazir Ahmad \\ Fakultas Ekonomi Universitas Negeri Jakarta \\ Email: ahmad72nazir@gmail.com \\ Tri Kurniati Khairunnisa \\ Fakultas Ekonomi Universitas Negeri Jakarta \\ Email: tri.kurniati.khairunnisa@gmail.com
}

Etty Gurendawati

Fakultas Ekonomi Universitas Negeri Jakarta

Email: egurendra@unj.ac.id

\begin{abstract}
ABSTRAK
Penelitian ini bertujuan untuk mengetahui pengaruh religiusitas, preferensi risiko, dan locus of control terhadap perilaku keuangan dan dampaknya terhadap personal financial distress pada pekerja muda di DKI Jakarta. Teknik pengambilan sampel dalam penelitian ini menggunakan purposive sampling dengan jumlah sampel 370 pekerja muda di DKI Jakarta. Pengumpulan data dilakukan dengan menggunakan kuesioner yang telah dibagikan secara langsung melalui formulir online (google-form) dan dilakukan uji instrumen validitas dan rentabilitas. Metode penelitian menggunakan pendekatan kuantitatif dengan teknik analisis data untuk menguji hipotesis menggunakan teknik SEM (Structrural Equation Modeling) PLS. Hasil penelitian menunjukkan bahwa: (1) religiusitas tidak terdapat pengaruh yang signifikan terhadap personal financial distress, (2) ada pengaruh positif dan signifikan: preferensi risiko terhadap personal financial distress, religiusitas dan locus of control terhadap perilaku keuangan, preferensi risiko terhadap personal financial distress melalui perilaku keuangan, (3) ada pengaruh negatif dan signifikan: locus of control dan perilaku keuangan terhadap personal financial distress, preferensi risiko terhadap perilaku keuangan, religiusitas dan locus of control terhadap personal financial distress melalu perilaku keuangan.
\end{abstract}

Kata kunci : Religiusitas, Preferensi Risiko, Locus of Control, Perilaku Keuangan, Personal Financial Distress 
Jurnal Riset Manajemen Sains Indonesia (JRMSI) | Vol 11, No. 2, 2020 e-ISSN: 2301-8313 http://doi.org/10.21009/JRMSI

\section{PENDAHULUAN}

Kaum muda saat ini menghadapi serangkaian tantangan yang mencakup sumber daya keuangan yang terbatas dan meningkatnya biaya (Lajuni, Bujang, Karia, \& Yacob, 2018). Hasil survei yang dilakukan oleh lembaga riset global Kadence International-Indonesia bertajuk Share of Wallet dengan melibatkan 3000 responden masyarakat Indonesia dari kelas bawah hingga kelas atas mengungkapkan bahwa 28 persen masyarakat Indonesia berada dalam kategori "Broke", atau kelompok yang pengeluarannya lebih besar dari pada pendapatannya, sehingga mengalami defisit sekitar 35 persen. Pengeluaran ini dilakukan untuk hidup mewah diluar penghasilannya (Dewi, 2013). Terlebih lagi dewasa ini, godaan berutang bagi setiap rumah tangga di negara berkembang termasuk Indonesia sangat besar. Dengan kemudahan teknologi digital, pengajuan pinjaman dapat dilakukan sangat cepat, mudah, dan dengan nilai yang besar. Otoritas Jasa Keuangan (OJK) memaparkan total pinjaman online yang disalurkan lewat teknologi finansial (fintech) pinjam meminjam uang (peer to peer/P2P lending) per Mei 2019 sebesar Rp41,04 triliun (Rika, 2019).

Kondisi ini semakin diperburuk dengan menurunnya indeks ekonomi masyarakat. Hasil Survei Konsumen Bank Indonesia pada Januari 2020 menunjukkan bahwa Indeks Kondisi Ekonomi (IKE) pada Januari 2020 sebesar 109,6 menurun dari bulan sebelumnya sebesar 113,1 (Bank Indonesia, 2020). Penurunan ini terutama disebabkan menurunnya keyakinan konsumen terhadap ketersediaan lapangan kerja dan penurunan penghasilan. Penurunan penghasilan dan sulitnya mencari lapangan kerja merupakan pemicu munculnya permasalahan keuangan pada tingkat individu maupun rumah tangga, terutama bagi mereka yang masih belum mapan secara mental dan usia. Masa muda adalah transisi kehidupan yang signifikan dan biasanya ditandai dengan kecemasan terhadap kondisi keuangan (Archuleta, Dale, \& Spann, 2013). Oleh karenanya, kaum muda lebih mudah terpapar stres akibat problematika keuangan dan mengalami financial distress.

Financial distress mengacu pada tekanan yang disebabkan oleh situasi keuangan dari pribadi, keluarga dan berbagai kondisi keuangan lainnya (Yu \& Jupri, 2015). Garman et al. (2004) mendefinisikan financial distress sebagai tekanan fisik dan mental yang intens mencakup keprihatinan dan kekhawatiran tentang masalah keuangan. Financial distress dapat berlangsung dalam waktu singkat atau tidak bisa menjadi kondisi persisten. Penyebab stressor yang berkontribusi terhadap financial distress antara lain: menerima teguran dari kreditur atas tagihan yang lewat tenggat waktu, mengeluarkan cek dengan dana yang tidak cukup, terlambat 
Jurnal Riset Manajemen Sains Indonesia (JRMSI) | Vol 11, No. 2, 2020 e-ISSN: 2301-8313 http://doi.org/10.21009/JRMSI

membayar tagihan, dan mengkhawatirkan persiapan finansial untuk pensiun (O’Neill, Sorhaindo, Prawitz, Kim, \& Garman, 2006). Kekhawatiran tentang uang, hutang, dan pembayaran tagihan mempengaruhi banyak aspek kehidupan seseorang, seperti kesehatan, produktivitas tempat kerja, dan hubungan keluarga (O’Neill et al., 2006).

Financial distress bagi setiap orang memiliki tingkatan yang berbeda dan disebabkan oleh faktor yang berbeda pula. Lajuni et al. (2018) menyatakan bahwa sumber variasi individu seperti religiusitas dan perilaku keuangan berkontribusi terhadap financial distress. Sipon et al. (2014) mengemukakan bahwa agama berdampak terhadap stres atas hutang finansial. Walau demikian, secara umum financial distress individu dipengaruhi oleh perilaku keuangan individu itu sendiri. Perilaku keuangan atau financial behaviour adalah pada bagaimana seseorang berperilaku dalam kaitannya dengan hal keuangan pribadi yang diukur dengan tindakan individu tersebut (Marsh, 2006). Stamp (2009) mengemukakan bahwa perilaku seperti kurangnya tanggung jawab pribadi, seperti penganggaran yang buruk dan salah urus uang, terlalu banyak menggunakan kredit dan pinjaman berlebihan, pengeluaran berlebihan, sikap negatif terhadap pembayaran tagihan, dan keengganan pembayaran hutang dapat berpengaruh pada financial distress.

Namun, perlu dicermati pula bahwa perilaku keuangan dipengaruhi oleh faktor internal dan eksternal. Faktor internal termasuk keadaan psikologis dan kognitif sementara faktor eksternal mencakup kondisi sosial dan ekonomi (Capuano \& Ramsay, 2011). Agama merupakan salah satu faktor eksternal, namun disisi lain juga dapat menjadi faktor internal ketika agama menjadi bagian dari kualitas penghayatan dan sikap hidup. Sehingga agama bukan hanya sebagai identitas namun juga lebih kepada tingkat kepatuhan dan keyakinan, atau religiusitas. Religiusitas adalah orientasi, rangkaian perilaku dan gaya hidup yang dianggap penting oleh sebagian besar orang di seluruh dunia yang tidak dapat diabaikan oleh psikologi sosial dan kepribadian lagi (Sedikides, 2010). Dengan demikian perilaku dan religiusitas individu saling berhubungan satu sama lain.

Faktor internal lainnya yang juga mempengaruhi perilaku keuangan adalah locus of control. Menurut Patten (2005) locus of control terkait dengan tingkat kepercayaan seseorang tentang peristiwa, nasib, kekayaan dan takdir yang terjadi dalam dirinya, baik karena faktor internal maupun faktor eksternal. Secara formal locus of control menggambarkan seberapa jauh seseorang memandang hubungan antara perbuatan yang dilakukannya dengan akibat/hasilnya atau cara pandang seseorang terhadap suatu peristiwa apakah seorang individu dapat atau tidak dapat mengendalikan peristiwa yang terjadi padanya. Kholilah \& Iramani (2013) menjelaskan 
Jurnal Riset Manajemen Sains Indonesia (JRMSI) | Vol 11, No. 2, 2020 e-ISSN: 2301-8313 http://doi.org/10.21009/JRMSI

bahwa semakin baik locus of control seseorang akan cenderung memiliki perilaku keuangan yang bijak.

Perilaku keuangan juga erat kaitannya dengan risiko. Karena disetiap keputusan keuangan yang kita ambil, pasti mengandung risiko didalamnya, terutama bagi kaum muda. Graham et al. (2018) menyatakan bahwa lapisan yang membentuk pengambilan risiko atau penghindaran risiko, dimulai dengan faktor kontekstual yang membuat kaum muda rentan atau tahan terhadap pengambilan risiko, termasuk proses internalisasi dan interpretasi risiko berikutnya dan pengambilan risiko. Karena itu preferensi risiko seseorang berhubungan dengan perilaku seseorang dalam membuat keputusan keuangan. Preferensi risiko didefinisikan sebagai kecenderungan seorang individu untuk memilih opsi berisiko (Hsee dan Weber, 1998). Penelitian yang dilakukan oleh León and Pfeifer (2017) menunjukkan bahwa preferensi individu sehubungan dengan pengambilan risiko memainkan peran penting dalam perilaku ekonomi keuangan dan dalam pasar keuangan.

Penelitian lainnya mengenai financial distress yang cukup banyak dilakukan adalah financial distress pada tingkat korporasi atau perusahaan (Alifiah, 2014; Saji, 2018), namun penelitian mengenai financial distress pada tingkat individu atau yang bisa disebut sebagai personal financial distress masih sangat minim dilakukan. Penelitian yang pernah dilakukan terkait personal financial distress antara lain oleh (Lajuni, Bujang, Karia, et al., 2018) yang menguji pengaruh religiusitas, pengetahuan keuangan dan perilaku keuangan terhadap financial distress, dan menemukan bahwa hanya pengetahuan keuangan dan perilaku keuangan yang memiliki pengaruh signifikan terhadap financial distress. Penelitian lain juga pernah dilakukan oleh Archuleta, Dale, \& Spann (2013) yang menguji pengaruh hutang, financial anxiety dan kepuasan finansial terhadap financial distress, dan menemukan bahwa hanya hutang dan financial anxiety yang memiliki pengaruh signifikan terhadap financial distress. Beberapa peneliti juga menguji financial distress dari sisi kesehatan (Bagwell, Dorothy $\mathrm{C}$. Kim, 2003; P Drentea \& Lavrakas, 2000; Patricia Drentea, 2000; Jacobson et al., 1996) dan beberapa peneliti menghubungkan fnancial distress dengan faktor sosiodemografi (Barton, Futris, \& Nielsen, 2015; Mills, Grasmick, Morgan, \& Wenk, 1992; Xu, Beller, Roberts, \& Brown, 2015).

Penelitian terkait financial distress ini masih merupakan topik yang menarik untuk dieksplorasi lebih jauh lagi. Berdasarkan penelitian yang pernah ada dapat terlihat bahwa terdapat celah penelitian, dimana financial distress akan diuji dari perspektif financial behavior atau perilaku keuangan beserta faktor-faktor penentunya yang berfokus pada variabel 
Jurnal Riset Manajemen Sains Indonesia (JRMSI) | Vol 11, No. 2, 2020 e-ISSN: 2301-8313 http://doi.org/10.21009/JRMSI

religiusitas, preferensi risiko, dan locus of control. Dengan demikian, pada penelitian ini akan dilakukan dua pengujian, yaitu pengujian pengaruh langsung variabel religiusitas, preferensi risiko, locus of control dan perilaku keuangan terhadap personal financial distress, dan pengujian pengaruh tidak langsung variabel religiusitas, preferensi risiko, locus of control terhadap personal financial distress melalui mediasi perilaku keuangan.

\section{Rumusan Masalah}

Berdasarkan latar belakang penelitian yang telah dikemukakan, maka dirumuskan permasalahan dalam penelitian ini adalah sebagai berikut: 1). Apakah religiusitas berpengaruh terhadap personal financial distress pekerja muda di DKI Jakarta? 2). Apakah preferensi risiko berpengaruh terhadap personal financial distress pekerja muda di DKI Jakarta? 3). Apakah locus of control berpengaruh terhadap personal financial distress pekerja muda di DKI Jakarta? 4). Apakah perilaku keuangan berpengaruh terhadap personal financial distress pekerja muda di DKI Jakarta? 5). Apakah religiusitas berpengaruh terhadap perilaku keuangan pekerja muda di DKI Jakarta? 6). Apakah preferensi risiko berpengaruh terhadap perilaku keuangan pekerja muda di DKI Jakarta? 7). Apakah locus of control berpengaruh terhadap perilaku keuangan pekerja muda di DKI Jakarta? 8). Apakah religiusitas berpengaruh terhadap personal financial distress melalui perilaku keuangan pekerja muda di DKI Jakarta? 9). Apakah preferensi risiko berpengaruh terhadap personal financial distress melalui perilaku keuangan pekerja muda di DKI Jakarta? 10). Apakah locus of control berpengaruh terhadap personal financial distress melalui perilaku keuangan pekerja muda di DKI Jakarta?

\section{Tujuan Penelitian}

Berdasarkan latar belakang penelitian dan rumusan masalah yang telah dikemukakan, maka tujuan penelitian ini adalah sebagai berikut: 1). Untuk mengetahui pengaruh religiusitas terhadap personal financial distress pekerja muda di DKI Jakarta; 2). Untuk mengetahui pengaruh preferensi risiko terhadap personal financial distress pekerja muda di DKI Jakarta; 3). Untuk mengetahui pengaruh locus of control terhadap personal financial distress pekerja muda di DKI Jakarta; 4). Untuk mengetahui pengaruh perilaku keuangan terhadap personal financial distress pekerja muda di DKI Jakarta; 5). Untuk mengetahui pengaruh religiusitas terhadap perilaku keuangan pekerja muda di DKI Jakarta; 6). Untuk mengetahui pengaruh preferensi risiko terhadap perilaku keuangan pekerja muda di DKI Jakarta; 7). Untuk mengetahui pengaruh locus of control terhadap perilaku keuangan pekerja muda di DKI Jakarta; 8). Untuk mengetahui pengaruh religiusitas terhadap personal financial distress 
Jurnal Riset Manajemen Sains Indonesia (JRMSI) | Vol 11, No. 2, 2020 e-ISSN: 2301-8313 http://doi.org/10.21009/JRMSI

melalui perilaku keuangan pekerja muda di DKI Jakarta; 9). Untuk mengetahui pengaruh preferensi risiko terhadap personal financial distress melalui perilaku keuangan pekerja muda di DKI Jakarta; 10). Untuk mengetahui pengaruh locus of control terhadap personal financial distress melalui perilaku keuangan pekerja muda di DKI Jakarta.

\section{TELAAH PUSTAKA \\ Personal Financial Distress}

Financial distress dapat didefinisikan sebagai reaksi, seperti ketidak nyamanan mental atau fisik, terhadap tekanan tentang keadaan kesejahteraan finansial umum seseorang, dan khususnya persepsi tentang kemampuan seseorang untuk mengelola sumber daya ekonomi (seperti pendapatan dan tabungan), membayar tagihan secara teratur, membayar hutang, dan memenuhi kebutuhan dan keinginan hidup (Garman et al., 2005). Penyebab financial distress seseorang mungkin berbeda dari penyebab financial distress yang lainnya (Yu \& Jupri, 2015). Banyak faktor yang dapat menyebabkan financial distress bagi seseorang. Ware (2015) menyoroti bahwa dua penyebab utama kesulitan keuangan adalah kemiskinan dan hutang yang tidak dapat dikelola.

Financial distress seringkali dikaitkan dengan financial well being, maka (Prawitz et al., 2006) mengembangkan skala FDFW (Financial Distress/Financial Well-Being) yang mempertimbangkan berbagai konsep keuangan pribadi, termasuk pertanyaan tentang topik kepuasan finansial, tekanan finansial, perasaan kesejahteraan finansial, perilaku finansial, dan dampaknya terhadap keluarga dan pekerjaan. Hal ini bertujuan untuk mengidentifikasi apa yang mungkin digambarkan secara luas sebagai berbagai konsep, masalah, dan komponen yang berkaitan dengan kesejahteraan finansial pribadi dan keluarga pada umumnya dan perilaku keuangan yang buruk ada pada khususnya (Prawitz et al., 2006).

\section{Perilaku Keuangan}

Perilaku keuangan atau financial behaviour sering juga diartikan sebagai financial management behaviour, yang dapat didefinisikan sebagai perilaku manusia yang relevan dengan manajemen uang (Özmete, 2015). Perilaku keuangan umum termasuk perilaku pengelolaan uang tunai, perilaku kredit dan perilaku tabungan (cash, credit and saving behavior) (Özmete, 2015).

Perilaku Keuangan juga mengacu pada bagaimana seseorang berperilaku dalam kaitannya dengan hal keuangan pribadi yang diukur dengan tindakan individu tersebut (Marsh, 
Jurnal Riset Manajemen Sains Indonesia (JRMSI) | Vol 11, No. 2, 2020 e-ISSN: 2301-8313 http://doi.org/10.21009/JRMSI

2006). Nofsinger (2003) mengemukakan bahwa perilaku keuangan yaitu mempelajari bagaimana manusia secara aktual berperilaku dalam sebuah penentuan keuangan. (financial setting), khususnya mempelajari bagaimana psikologi mempengaruhi keputusan keuangan, perusahaan dan pasar keuangan. Perilaku keuangan mencerminkan bagaimana perilaku manusia relevan dengan manajemen keuangan (Xiao, 2009). Tujuan dari perilaku keuangan adalah untuk memahami dan memprediksi implikasi sistematis pasar keuangan dari sudut pandang psikologis (Arifin, 2018).

\section{Religiusitas}

Religiosity adalah istilah yang lebih mengarah pada kualitas penghayatan dan sikap hidup seseorang berdasarkan nilai-nilai kegamaan yang diyakininya. Sedikides (2010) mendefinisikan religiusitas sebagai orientasi, rangkaian perilaku dan gaya hidup yang dianggap penting oleh sebagian besar orang di seluruh dunia yang tidak dapat diabaikan oleh psikologi sosial dan kepribadian lagi. Iddagoda and Opatha (2017) mendefinisikan religiusitas sebagai sejauh mana seseorang tertentu percaya dan memuliakan pencipta, tuhan, dewa atau dewi agama yang relevan, kemudian mempraktikkan pengajaran yang relevan dan berpartisipasi dalam kegiatan yang relevan. Lebih lanjut, (Iddagoda \& Opatha, 2017) mengukur religiusitas kedalam tiga dimensi yaitu: Kesalehan, Praktek, Partisipasi.

\section{Preferensi Risiko}

Preferensi risiko didefinisikan sebagai kecenderungan seorang individu untuk memilih opsi berisiko (Hsee dan Weber, 1998). Preferensi risiko mengacu pada sikap orang terhadap risiko, yang merupakan faktor kunci dalam studi tentang perilaku pengambilan keputusan investor (Wen, He, \& Chen, 2014). Lebih lanjut, Wen et al. (2014) mengemukakan bahwa preferensi risiko bervariasi berdasarkan waktu dan berpengaruh terhadap status untung dan rugi, nilai pengembalian, dan beberapa faktor lainnya, seperti preferensi risiko dan kesalahan residual periode yang lalu. Preferensi risiko juga disebut 'sikap berisiko,' 'toleransi risiko' atau 'sensitivitas terhadap risiko' sering dipahami untuk mewakili karakteristik pribadi (Hertwig, Wulff, \& Mata, 2018).

\section{Locus of Control}

Locus of control adalah konsep kepribadian yang awalnya diusulkan oleh (Rotter, 1966), yang didefinisikan sebagai harapan atau keyakinan abadi yang digeneralisasi tentang seberapa responsif dan terkontrolnya lingkungan. Locus of control merepresentasikan kecenderungan 
Jurnal Riset Manajemen Sains Indonesia (JRMSI) | Vol 11, No. 2, 2020 e-ISSN: 2301-8313 http://doi.org/10.21009/JRMSI

seseorang sebagai pengontrol atau dikontrol oleh kejadian eksternal (Ziemkiewicz et al., 2011). Locus of control adalah sebuah konsep psikologi mengenai keyakinan seseorang tentang sejauh mana mereka mengendalikan peristiwa yang mempengaruhi mereka (Cobb-Clark, Kassenboehmer, \& Sinning, 2016).

Rotter (1966) membagi locus of control menjadi dua, yaitu locus of control internal dan locus of control eksternal. Dimana Individu dengan locus of control internal cenderung menganggap bahwa keterampilan (skill), kemampuan (ability), dan usaha (effort) lebih menentukan apa yang diperoleh dalam hidup. Sebaliknya, individu yang memiliki locus of control eksternal cenderung menganggap bahwa hidup ditentukan oleh kekuatan dari luar diri, seperti nasib, takdir, keberuntungan, dan orang lain yang berkuasa. Lebih lanjut Rotter (1966) mengembangkan Locus of Control Scale yang terdiri dari 23 item pertanyaan untuk menilai apakah seseorang memiliki kecenderungan untuk memikirkan situasi dan kejadian berada dibawah kendali mereka sendiri atau berada dibawah kendali pengaruh eksternal. Skala ini menggunakan pendekatan dimana seseorang memilih salah satu dari dua pernyataan sehingga dapat diinterpretasi sebagai internal atau eksternal.

\section{MODEL PENELITIAN}

Berdasarkan kerangka teoritis yang telah dikemukakan di atas, maka model penelitian yang diajukan dapat terlihat pada gambar berikut di bawah ini.

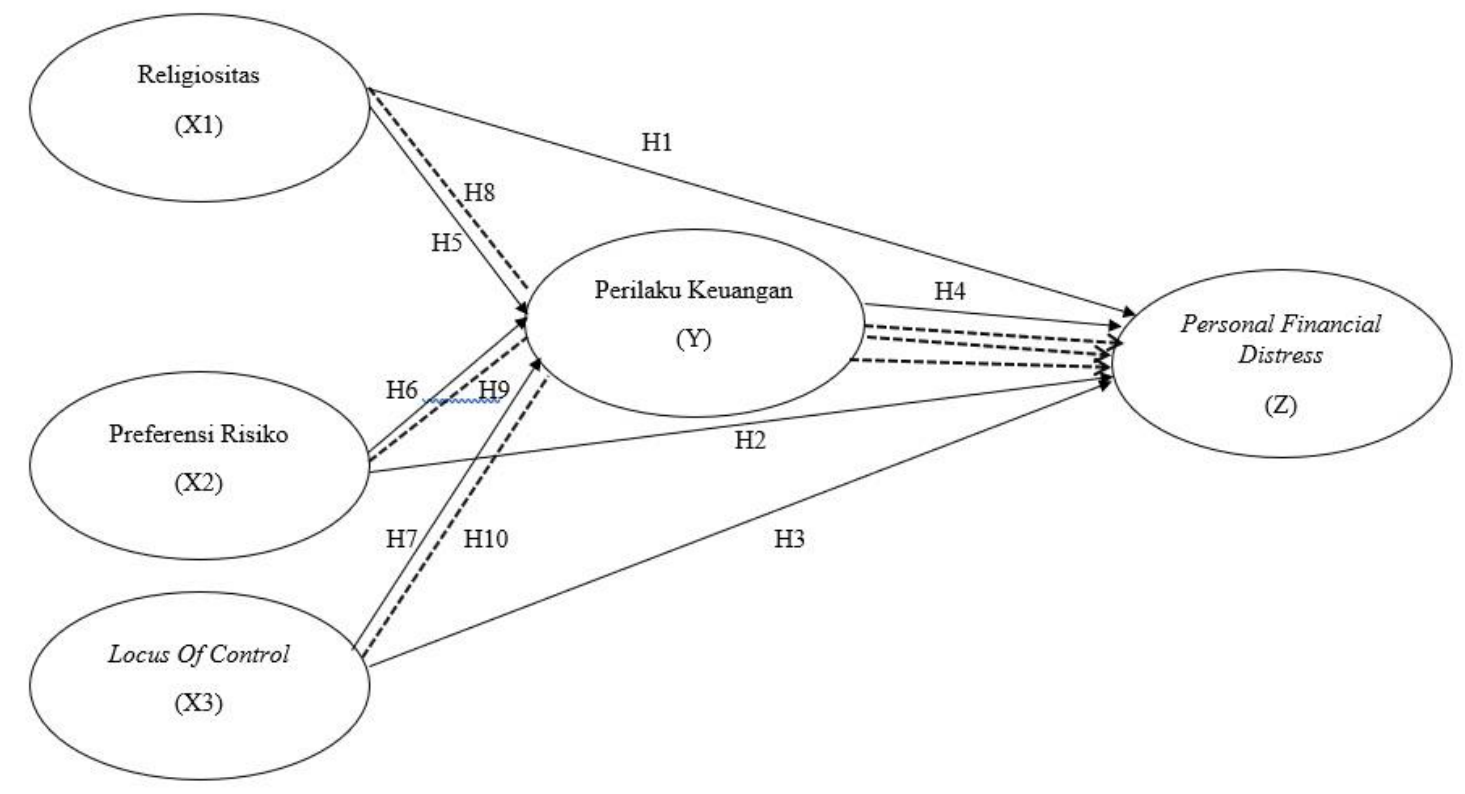

Gambar 1. Kerangka Model Penelitian 
Jurnal Riset Manajemen Sains Indonesia (JRMSI) | Vol 11, No. 2, 2020 e-ISSN: 2301-8313 http://doi.org/10.21009/JRMSI

\section{HIPOTESIS PENELITIAN}

Berdasarkan kerangka model penelitian yang telah dikemukakan sebelumnya, maka hipotesis dalam penelitian ini sebagai berikut:

H1 : Religiusitas mempengaruhi Personal Financial Distress

H2 : Preferensi Risiko mempengaruhi Personal Financial Distress

H3 : Locus Of Control mempengaruhi Personal Financial Distress

H4 : Perilaku Keuangan mempengaruhi Personal Financial Distress

H5 : Religiusitas mempengaruhi Perilaku Keuangan

H6 : Preferensi Risiko mempengaruhi Perilaku Keuangan

H7 : Locus Of Control mempengaruhi Perilaku Keuangan

H8 : Religiusitas mempengaruhi Personal Financial Distress melalui Perilaku Keuangan

H9 : Preferensi Risiko mempengaruhi Personal Financial Distress melalui Perilaku Keuangan H10 : Locus Of Control mempengaruhi Personal Financial Distress melalui Perilaku Keuangan

\section{HASIL DAN PEMBAHASAN \\ Profil Responden}

Profil responden yang diteliti meliputi usia, jenis kelamin, status pernikahan, pendidikan terakhir, lama bekerja dan pendapatan sebagai berikut:

Tabel 1. Profil Responden Berdasarkan Usia

\begin{tabular}{cccc}
\hline No & Usia & Jumlah responden & Persentase $(\%)$ \\
\hline 1 & $16-20$ Tahun & 6 & 1,6 \\
2 & $21-25$ Tahun & 97 & 26,2 \\
3 & $26-30$ Tahun & 267 & 72,2 \\
& Total & 370 & 100 \\
\hline
\end{tabular}

Tabel 2. Profil Responden Berdasarkan Jenis Kelamin

\begin{tabular}{cccc}
\hline No & Jenis Kelamin & Jumlah Responden & Persentase $(\%)$ \\
\hline 1 & Pria & 139 & 37,6 \\
2 & Wanita & 231 & 62,4 \\
& Total & 370 & 100 \\
\hline
\end{tabular}

Tabel 3. Profil Responden Berdasarkan Status Pernikahan

\begin{tabular}{clcc}
\hline No & \multicolumn{1}{c}{ Status Pernikahan } & Jumlah responden & Persentase $(\%)$ \\
\hline 1 & Belum Menikah & 168 & 45,4 \\
2 & Menikah & 193 & 52,2 \\
3 & Janda/Duda, Cerai/mati & 9 & 2,4 \\
& $\quad$ Total & 370 & 100 \\
\hline
\end{tabular}

Tabel 4. Profil Responden Berdasarkan Pendidikan 
Jurnal Riset Manajemen Sains Indonesia (JRMSI) | Vol 11, No. 2, 2020 e-ISSN: 2301-8313 http://doi.org/10.21009/JRMSI

\begin{tabular}{clcc}
\hline No & \multicolumn{1}{c}{ Pendidikan } & Jumlah responden & Persentase $(\%)$ \\
\hline 1 & SMA & 45 & 12,2 \\
2 & DIII & 6 & 1,6 \\
3 & Sarjana/ D IV & 288 & 77,8 \\
4 & Magister/ Pascasarjana & 31 & 8,4 \\
& $\quad$ Total & 370 & 100,0 \\
\hline
\end{tabular}

Tabel 5. Profil Responden Berdasarkan Lama Bekerja

\begin{tabular}{cccc}
\hline No & Lama Bekerja & Jumlah responden & Persentase $(\%)$ \\
\hline 1 & $1-3$ Tahun & 132 & 35,7 \\
2 & 3 - 5 Tahun & 82 & 22,2 \\
3 & $>$ 5 Tahun & 156 & 42,2 \\
& Total & 370 & 100 \\
\hline
\end{tabular}

Tabel 6. Profil Responden Berdasarkan Pendapatan

\begin{tabular}{cccc}
\hline No & Pendapatan & Jumlah responden & Persentase $(\%)$ \\
\hline 1 & Rp 3.500.000 - Rp 4.999.999 & 217 & 58,6 \\
2 & Rp 5.000.000 - Rp 9.999.999 & 110 & 29,7 \\
3 & $\geq$ Rp 10.000.000 & 43 & 11,6 \\
& Total & 370 & 100 \\
\hline
\end{tabular}

Sumber : Data primer diolah peneliti (2020)

Dari berbagai tabel di atas dapat terlihat bahwa dari 370 total responden yang terlibat dalam penelitian ini didominasi oleh usia 26 - 30 tahun sebanyak 267 responden $(72,2 \%)$. Selain itu responden juga didominasi oleh berjenis kelamin wanita sebanyak 231 responden $(62,4 \%)$. Kemudian dilihat dari status pernikahan sebanyak 193 responden $(52,2 \%)$ berstatus menikah. Sebagian besar responden berpendidikan Sarjana/D IV sebanyak 288 responden $(77,8 \%)$. Lama bekerja responden didominasi oleh telah bekerja selama $>5$ Tahun sebanyak 156 responden (42,2\%). Dilihat dari sis pendapatan sebanyak 217 responden $(58,6 \%)$ memiliki pendapatan Rp 3.500.000 - Rp 4.999.999.

\section{Hasil Pengujian Data \\ Uji Validitas}

Uji validitas dilakukan dengan bantuan software SPSS 25. Pengujian ini dilakukan dengan cara membandingkan nilai $\mathrm{r}$ hitung (pearson corellation) dengan $\mathrm{r}$ tabel. Item dinyatakan valid dan dapat digunakan untuk penelitian jika $r$ hitung lebih besar dari $r$ tabel dan bernilai positif (Ghozali, 2016). Pengambilan keputusan dilakukan pada taraf degree of freedom $(\mathrm{df})=\mathrm{n}-2$, dimana $\mathrm{n}=370$, sehingga $\mathrm{df}=370-2=368$ dengan siginifikansi $5 \%$ (tingkat kepercayaan 95\% atau $\alpha=0,05)$, sehingga nilai $\mathrm{r}$ tabel diketahui sebesar $\mathbf{0 , 1 0 2}$. Hasil uji validitas data dapat dilihat pada Tabel di bawah.

Tabel 7. Hasil Uji Validitas Variabel Personal Financial Distress

\begin{tabular}{cccc}
\hline Indikator & r Hitung & r Tabel & Uji Validitas \\
\hline
\end{tabular}


Jurnal Riset Manajemen Sains Indonesia (JRMSI) | Vol 11, No. 2, 2020 e-ISSN: 2301-8313 http://doi.org/10.21009/JRMSI

\begin{tabular}{llll}
\hline PFD1 & $0,881^{* *}$ & 0,102 & Valid \\
PFD2 & $0,671^{* *}$ & 0,102 & Valid \\
PFD3 & $0,700^{* *}$ & 0,102 & Valid \\
PFD4 & $0,823^{* *}$ & 0,102 & Valid \\
PFD5 & $0,708^{* *}$ & 0,102 & Valid \\
PFD6 & $0,776^{* *}$ & 0,102 & Valid \\
PFD7 & $0,677^{* *}$ & 0,102 & Valid \\
PFD8 & $0,797^{* *}$ & 0,102 & Valid \\
\hline
\end{tabular}

** Correlation is significant at the 0.01 level (2-tailed).

Tabel 8. Hasil Uji Validitas Variabel Financial Behavior

\begin{tabular}{lccc}
\hline Indikator & r Hitung & r Tabel & Uji Validitas \\
\hline FB1 & $0,780^{* *}$ & 0,102 & Valid \\
FB2 & $0,771^{* *}$ & 0,102 & Valid \\
FB3 & $0,542^{* *}$ & 0,102 & Valid \\
FB4 & $0,700^{* *}$ & 0,102 & Valid \\
FB5 & $0,809^{* *}$ & 0,102 & Valid \\
FB6 & $0,663^{* *}$ & 0,102 & Valid \\
\hline
\end{tabular}

** Correlation is significant at the 0.01 level (2-tailed).

Tabel 9. Hasil Uji Validitas Variabel Religiusitas

\begin{tabular}{lrrc}
\hline Indikator & r Hitung & r Tabel & Uji Validitas \\
\hline REL1 & $0,797^{* *}$ & 0,102 & Valid \\
REL2 & $0,790^{* *}$ & 0,102 & Valid \\
REL3 & $0,753^{* *}$ & 0,102 & Valid \\
REL4 & $0,797^{* *}$ & 0,102 & Valid \\
REL5 & $0,780^{* *}$ & 0,102 & Valid \\
REL6 & $0,719^{* *}$ & 0,102 & Valid \\
REL7 & $0,742^{* *}$ & 0,102 & Valid \\
\hline
\end{tabular}

** Correlation is significant at the 0.01 level (2-tailed).

Tabel 10. Hasil Uji Validitas Variabel Preferensi Risiko

\begin{tabular}{lccc}
\hline Indikator & r Hitung & r Tabel & Uji Validitas \\
\hline RISK1 & $0,650^{* *}$ & 0,102 & Valid \\
RISK2 & $0,730^{* *}$ & 0,102 & Valid \\
RISK3 & $0,759^{* *}$ & 0,102 & Valid \\
RISK4 & $0,809^{* *}$ & 0,102 & Valid \\
RISK5 & $0,783^{* *}$ & 0,102 & Valid \\
RISK6 & $0,706^{* *}$ & 0,102 & Valid \\
RISK7 & $0,751^{* *}$ & 0,102 & Valid \\
RISK8 & $0,722^{* *}$ & 0,102 & Valid \\
RISK9 & $0,580^{* *}$ & 0,102 & Valid \\
\hline
\end{tabular}

** Correlation is significant at the 0.01 level (2-tailed).

Tabel 11. Hasil Uji Validitas Variabel Locus of Control

\begin{tabular}{lrrc}
\hline Indikator & r Hitung & r Tabel & Uji Validitas \\
\hline LOC1 & $0,249^{* *}$ & 0,102 & Valid \\
LOC2 & $0,751^{* *}$ & 0,102 & Valid \\
\hline
\end{tabular}


Jurnal Riset Manajemen Sains Indonesia (JRMSI) | Vol 11, No. 2, 2020 e-ISSN: 2301-8313 http://doi.org/10.21009/JRMSI

\begin{tabular}{llll}
\hline LOC3 & $0,674 * *$ & 0,102 & Valid \\
LOC4 & $0,717^{* *}$ & 0,102 & Valid \\
LOC5 & $0,712^{* *}$ & 0,102 & Valid \\
LOC6 & $0,741^{* *}$ & 0,102 & Valid \\
LOC7 & $0,759^{* *}$ & 0,102 & Valid \\
\hline
\end{tabular}

** Correlation is significant at the 0.01 level (2-tailed).

Pada aplikasi SPSS 25 tanda ** pada nilai $\mathrm{r}$ hitung (pearson correlation) sudah menunjukkan bahwa indikator tersebut valid pada level signifikansi 0.05 (uji dua arah). Sehingga berdasarkan tabel di atas dapat dikatakan bahwa item-item yang digunakan dalam penelitian ini memiliki nilai $\mathrm{r}$ hitung $>0.0875$ dan memiliki tanda $* *$ yang artinya butir-butir pernyataan dalam kuesioner telah valid.

\section{Uji Reliabilitas}

Uji reliabilitas dilakukan secara one shot aatau pengukuran satu kali saja dengan menggunakan software SPSS 25. Uji reliabilitas dilakukan melalui pengukuran Alpha Cronbach. Suatu variabel dikatakan memiliki tingkat reliabel tinggi jika nilai koefisien Crobach Alpha $(\alpha)>0,70$ (Ghozali, 2016). Hasil uji reliabilitas penelitian ini tersaji pada tabel di bawah.

Tabel 12. Hasil Uji Reliabilitas

\begin{tabular}{lccc}
\hline \multicolumn{1}{c}{ Variabel } & Cronbach Alpha & Cut off value & Reliabilitas \\
\hline Personal Financial Distress & 0,891 & 0,70 & Reliabel \\
Perilaku Keuangan & 0,804 & 0,70 & Reliabel \\
Religiusitas & 0,884 & 0,70 & Reliabel \\
Preferensi Risiko & 0,885 & 0,70 & Reliabel \\
Locus of Control & 0,784 & 0,70 & Reliabel \\
\hline
\end{tabular}

Sumber: Output SPSS 25 diolah peneliti (2020)

. Tabel 12 memperlihatkan bahwa seluruh variabel yang digunakan dalam penelitian ini dinyatakan konsisten atau stabil karena setiap variabel yang diteliti memiliki nilai Crobach Alpha $(\alpha)$ lebih besar dari 0,7.

Maka berdasarkan hasil pengujian validitas dan reliabilitas yang telah diuraikan, dapat disimpulkan bahwa seluruh pernyataan yang digunakan dalam penelitian ini sudah teruji kesahihan (validity) serta keandalannya (reliability) sehingga seluruh pernyataan layak digunakan sebagai alat ukur penelitian. 
Jurnal Riset Manajemen Sains Indonesia (JRMSI) | Vol 11, No. 2, 2020 e-ISSN: 2301-8313 http://doi.org/10.21009/JRMSI

\section{Hasil Hipotesis dengan Menggunakan SEM}

Berikut ini merupakan model dan tabel yang menunjukkan hasil pengujian hipotesis dalam penelitian dengan menggunakan SEM-PLS.

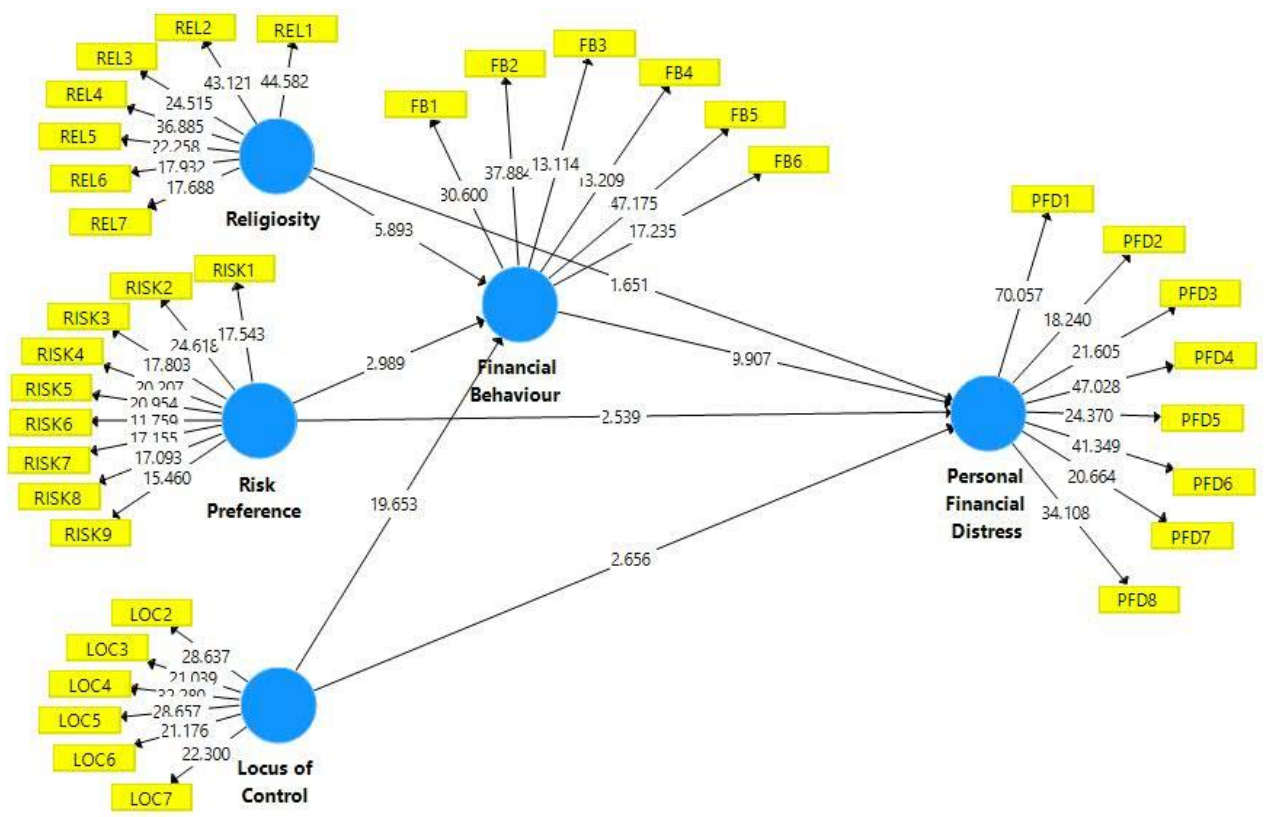

Gambar 2. Model Structural hasil Bootstrapping

Tabel 13. Hasil Uji Hipotesis

\begin{tabular}{|c|c|c|c|c|c|c|}
\hline & Hipotesis & $\begin{array}{l}\text { Original } \\
\text { Sample }\end{array}$ & $\begin{array}{c}\mathbf{T} \\
\text { Statistics }\end{array}$ & P Values & Pengaruh & Keputusan \\
\hline $\mathrm{H} 1$ & $\begin{array}{l}\text { Religiosity } \rightarrow \text { Personal } \\
\text { Financial Distress }\end{array}$ & $-0,074$ & 1,651 & 0,099 & $\begin{array}{c}\text { Tidak } \\
\text { Signifikan }\end{array}$ & $\begin{array}{l}\text { Hipotesis } \\
\text { ditolak }\end{array}$ \\
\hline $\mathrm{H} 2$ & $\begin{array}{l}\text { Risk Preference } \rightarrow \\
\text { Personal Financial } \\
\text { Distress }\end{array}$ & 0,110 & 2,539 & 0,011 & Signifikan & $\begin{array}{l}\text { Hipotesis } \\
\text { diterima }\end{array}$ \\
\hline $\mathrm{H} 3$ & $\begin{array}{l}\text { Locus of Control } \rightarrow \\
\text { Personal Financial } \\
\text { Distress }\end{array}$ & $-0,123$ & 2,656 & 0,008 & Signifikan & $\begin{array}{l}\text { Hipotesis } \\
\text { diterima }\end{array}$ \\
\hline $\mathrm{H} 4$ & $\begin{array}{l}\text { Financial Behaviour } \rightarrow \\
\text { Personal Financial } \\
\text { Distress }\end{array}$ & $-0,491$ & 9,907 & 0,000 & Signifikan & $\begin{array}{l}\text { Hipotesis } \\
\text { diterima }\end{array}$ \\
\hline H5 & $\begin{array}{l}\text { Religiosity } \rightarrow \text { Financial } \\
\text { Behaviour }\end{array}$ & 0,190 & 5,893 & 0,000 & Signifikan & $\begin{array}{l}\text { Hipotesis } \\
\text { diterima }\end{array}$ \\
\hline H6 & $\begin{array}{l}\text { Risk Preference } \rightarrow \\
\text { Financial Behaviour }\end{array}$ & $-0,115$ & 2,989 & 0,003 & Signifikan & $\begin{array}{l}\text { Hipotesis } \\
\text { diterima }\end{array}$ \\
\hline $\mathrm{H} 7$ & $\begin{array}{l}\text { Locus of Control } \rightarrow \\
\text { Financial Behaviour }\end{array}$ & 0,637 & 19,653 & 0,000 & Signifikan & $\begin{array}{l}\text { Hipotesis } \\
\text { diterima }\end{array}$ \\
\hline H8 & $\begin{array}{l}\text { Religiosity } \rightarrow \text { Financial } \\
\text { Behaviour } \rightarrow \text { Personal } \\
\text { Financial Distress }\end{array}$ & $-0,093$ & 4,770 & 0,000 & Signifikan & $\begin{array}{l}\text { Hipotesis } \\
\text { diterima }\end{array}$ \\
\hline H9 & $\begin{array}{l}\text { Risk Preference } \rightarrow \\
\text { Financial Behaviour } \rightarrow \\
\text { Personal Financial } \\
\text { Distress }\end{array}$ & 0,057 & 2,904 & 0,004 & Signifikan & $\begin{array}{c}\text { Hipotesis } \\
\text { diterima }\end{array}$ \\
\hline H10 & $\begin{array}{l}\text { Locus of Control } \rightarrow \\
\text { Financial Behaviour } \rightarrow\end{array}$ & $-0,313$ & 9,004 & 0,000 & Signifikan & $\begin{array}{l}\text { Hipotesis } \\
\text { diterima }\end{array}$ \\
\hline
\end{tabular}


Jurnal Riset Manajemen Sains Indonesia (JRMSI) | Vol 11, No. 2, 2020 e-ISSN: 2301-8313 http://doi.org/10.21009/JRMSI

\author{
Personal Financial \\ Distress \\ Sumber: Output SmartPLS 3.3.2, diolah peneliti (2020)
}

Untuk menguji pengaruh antar variabel dalam penelitian ini, peneliti menggunakan Structural Equation Modelling dengan sofware SmartPLS. Hasil dari uji hipotesis pertama diperoleh nilai t-statistik sebesar 1,651 lebih kecil dari nilai t-tabel (1.960). Diperoleh pula nilai $p$-values sebesar 0,099 atau p values $>0.050$. Hasil tersebut mengindikasikan bahwa terdapat pengaruh yang tidak signifikan antara religiusitas terhadap personal financial distress. Selain itu pada estimasi koefisien jalur, dihasilkan nilai original sample negatif sebesar -0,074 yang menandakan bahwa hubungan antara variabel religiusitas dan personal financial distress memiliki arah yang negatif, namun pengaruhnya tidak signifikan. Dengan demikian Hipotesis H1 ditolak, bahwa tidak terdapat pengaruh signifikan antara religiusitas terhadap personal financial distress pada pekerja muda di DKI Jakarta. Hasil penelitian ini konsisten dengan penelitian Lajuni et al. (2018) yang menemukan bahwa religiusitas tidak memiliki pengaruh signifikan terhadap personal financial distress. Tidak ada keraguan bahwa terdapat hubungan substansial antara mengatasi stres finansial dan religiusitas (Onyima \& Nkechi, 2017). Namun menurut LeBaron, Kelley, Hill, \& Galbraith (2019) dalam beberapa keadaan, agama dapat membahayakan individu, dan dalam beberapa keadaan lain, agama dapat membantu individu. Beberapa orang mengalami tekanan keuangan, sebagian karena tuntutan agama mereka pada waktu dan uang mereka (LeBaron et al., 2019).

Selanjutnya hipotesis kedua diperoleh nilai t-statistik sebesar 2,539 lebih besar dari nilai t-tabel (1.960). Diperoleh pula nilai $p$-values sebesar 0,011 atau p values $<0.050$. Hasil tersebut mengindikasikan bahwa terdapat pengaruh signifikan antara preferensi risiko terhadap personal financial distress. Selain itu pada estimasi koefisien jalur, dihasilkan nilai original sample positif sebesar 0,110 yang menandakan bahwa hubungan antara variabel preferensi risiko dan personal financial distress memiliki arah yang positif. Dengan demikian Hipotesis H2 diterima, bahwa terdapat pengaruh signifikan positif antara preferensi risiko terhadap personal financial distress pada pekerja muda di DKI Jakarta. Hasil penelitian yang relevan mendekati adalah penelitian Dalton et al. (2019) terhadap wiraswasta kecil (microentrepreneur) mengenai perilaku pengambilan risiko (risk taking behavior) terhadap kekhawatiran keuangan (financial worries) yang menunjukkan bahwa kekhawatiran keuangan meningkatkan tingkat stres dan mengurangi tingkat keengganan risiko. 
Jurnal Riset Manajemen Sains Indonesia (JRMSI) | Vol 11, No. 2, 2020 e-ISSN: 2301-8313 http://doi.org/10.21009/JRMSI

Untuk hipotesis yang ketiga diperoleh nilai t-statistik sebesar 2,656 lebih besar dari nilai t-tabel (1.960). Diperoleh pula nilai $p$-values sebesar 0,008 atau p values $<0.050$. Hasil tersebut mengindikasikan bahwa terdapat pengaruh signifikan antara locus of control terhadap personal financial distress. Selain itu pada estimasi koefisien jalur, dihasilkan nilai original sample negatif sebesar -0,123 yang menandakan bahwa hubungan antara variabel locus of control dan personal financial distress memiliki arah negatif. Dengan demikian Hipotesis H3 diterima, bahwa terdapat pengaruh signifikan negatif antara locus of control terhadap personal financial distress. Hasil yang negatif pada penelitian ini menunjukkan bahwa dalam menghadapi peristiwa atau situasi negatif yaitu kesulitan keuangan, locus of control internal responden berperan lebih sedikit daripada locus of control eksternal mereka. Hal ini sejalan dengan pernyataan (Krause, Jay, \& Liang, 1991) bahwa locus control eksternal yang lebih besar terkait dengan peningkatan tekanan keuangan (financial strain). Dessart \& Kuylen (1986) juga menemukan bahwa orang yang memiliki locus of control eksternal dalam orientasi mereka lebih mungkin mengalami kesulitan keuangan.

Selanjutnya hipotesis keempat diperoleh nilai t-statistik sebesar 9,907 lebih besar dari nilai t-tabel (1.960). Diperoleh pula nilai $p$-values sebesar 0,000 atau $\mathrm{p}$ values $<0.050$. Hasil tersebut mengindikasikan bahwa terdapat pengaruh signifikan antara perilaku keuangan terhadap personal financial distress. Selain itu pada estimasi koefisien jalur, dihasilkan nilai original sample negatif sebesar -0,491 yang menandakan bahwa hubungan antara variabel perilaku keuangan dan personal financial distress memiliki arah yang negatif. Dengan demikian Hipotesis H4 diterima, bahwa terdapat pengaruh signifikan negatif antara perilaku keuangan terhadap personal financial distress pada pekerja muda di DKI Jakarta. Hasil penelitian ini sejalan dengan beberapa penelitian terdahulu (Hayhoe, Leach, Turner, Bruin, \& Lawrence, 2000; Lajuni, Bujang, \& Aziz Karia, 2018; Marlina, Irawati, Sadalia, \& Muda, 2019) yang menyatakan bahwa perilaku keuangan positif terkait dengan penurunan tekanan keuangan, artinya perilaku keuangan berhubungan negatif dengan peningkatan personal financial distress. Hal ini berarti bahwa jika seseorang ingin terhindar dari financial distress maka harus mengelola dengan baik keuangannya (Marlina et al., 2019).

Hipotesis kelima diperoleh nilai t-statistik sebesar 5,893 lebih besar dari nilai t-tabel (1.960). Diperoleh pula nilai $p$-values sebesar 0,000 atau $\mathrm{p}$ values $<0.050$. Hasil tersebut mengindikasikan bahwa terdapat pengaruh signifikan antara religiusitas terhadap perilaku keuangan. Selain itu pada estimasi koefisien jalur, dihasilkan nilai original sample positif 
Jurnal Riset Manajemen Sains Indonesia (JRMSI) | Vol 11, No. 2, 2020 e-ISSN: 2301-8313 http://doi.org/10.21009/JRMSI

sebesar 0,190 yang menandakan bahwa hubungan antara variabel religiusitas dan perilaku keuangan memiliki arah yang positif. Dengan demikian Hipotesis H5 diterima, bahwa terdapat pengaruh signifikan positif antara religiusitas terhadap perilaku keuangan pekerja muda di DKI Jakarta. Hasil penelitian ini sejalan dengan Hess, (2012); Lajuni, Bujang, \& Aziz Karia, (2018) yang menunjukkan bahwa religiusitas memiliki pengaruh signifikan positif pada perilaku keuangan. Individu dengan norma sosial keagamaan yang kuat cenderung memiliki skor kredit yang secara signifikan lebih tinggi serta tingkat saldo kartu kredit, penyitaan, dan kebangkrutan yang secara signifikan lebih rendah dibandingkan dengan individu dengan tingkat religiusitas yang lebih rendah (Hess, 2012). Temuan penelitian ini juga mendukung hasil penelitian (León \& Pfeifer, 2017) yang memberikan bukti empiris bahwa terdapat perbedaan perilaku keuangan antara rumah tangga religius dan non-religius.

Hipotesis selanjutnya yaitu keenam diperoleh nilai t-statistik sebesar 2,989 lebih besar dari nilai t-tabel (1.960). Diperoleh pula nilai $p$-values sebesar 0,003 atau p values $<0.050$. Hasil tersebut mengindikasikan bahwa terdapat pengaruh signifikan antara preferensi risiko terhadap perilaku keuangan. Selain itu pada estimasi koefisien jalur, dihasilkan nilai original sample negatif sebesar -0,115 yang menandakan bahwa hubungan antara variabel preferensi risiko dan perilaku keuangan memiliki arah yang negatif. Dengan demikian Hipotesis H6 diterima, bahwa terdapat pengaruh signifikan negatif antara preferensi risiko terhadap perilaku keuangan pekerja muda di DKI Jakarta. Hasil penelitian ini sejalan dengan penelitian (Vermeer \& Sanfey, 2015) bahwa preferensi risiko berpengaruh terhadap perilaku keuangan dan salah satu pengaruhnya dapat besifat negatif. Oleh karena itu, mempertimbangkan perilaku berisiko dalam situasi yang sama persis menghasilkan hubungan antar generasi yang sama dengan pendekatan yang mempertimbangkan preferensi risiko (Mata, Frey, Richter, Schupp, \& Hertwig, 2018).

Untuk hipotesis ketujuh diperoleh nilai t-statistik sebesar 19,653 lebih besar dari nilai ttabel (1.960). Diperoleh pula nilai $p$-values sebesar 0,000 atau p values $<0.000$. Hasil tersebut mengindikasikan bahwa terdapat pengaruh signifikan antara locus of control terhadap perilaku keuangan. Selain itu pada estimasi koefisien jalur, dihasilkan nilai original sample positif sebesar 0,637 yang menandakan bahwa hubungan antara variabel locus of control dan perilaku keuangan memiliki arah yang positif. Dengan demikian Hipotesis $\mathrm{H} 7$ diterima, bahwa terdapat pengaruh signifikan positif antara locus of control terhadap perilaku keuangan pekerja muda di DKI Jakarta. Hasil penelitian ini sejalan dengan (Kholilah \& Iramani, 2013; Perry \& Morris, 
Jurnal Riset Manajemen Sains Indonesia (JRMSI) | Vol 11, No. 2, 2020 e-ISSN: 2301-8313 http://doi.org/10.21009/JRMSI

2005) yang menunjukkan bahwa locus of control berpengaruh secara positif terhadap perilaku pengelolaan keuangan. Seperti yang dikemukakan oleh Rotter (1966) konsep mengenai locus of control dapat dilihat bahwa locus of control dibagi menjadi dua, yaitu ekternal dan internal. Locus of control yang positif menunjukkan bahwa locus of control internal lebih berperan dalam pengelolaan manejemen keuangan, sedangkan locus of control eksternal akan cenderung kurang mengeluarkan upaya yang diperlukan untuk menunjukkan perilaku manajemen keuangan yang bertanggung jawab.

Dalam pengujian hipotesis selanjutnya yaitu kedelapan diperoleh nilai t-statistik sebesar 4,770 lebih besar dari nilai t-tabel (1.960). Diperoleh pula nilai $p$-values sebesar 0,000 atau $\mathrm{p}$ values $<0.050$. Hasil tersebut mengindikasikan bahwa terdapat pengaruh signifikan antara religiusitas terhadap personal financial distress melalui perilaku keuangan. Selain itu pada estimasi koefisien jalur, dihasilkan nilai original sample negatif sebesar -0,093 yang menandakan bahwa hubungan antara variabel religiusitas, perilaku keuangan dan personal financial distress memiliki arah yang negatif. Dengan demikian Hipotesis H8 diterima, bahwa terdapat pengaruh signifikan antara religiusitas terhadap personal financial distress melalu perilaku keuangan pada pekerja muda di DKI Jakarta. Menurut Shweder (1991), agama adalah salah satu lembaga sosial yang paling universal dan berpengaruh dan memiliki pengaruh yang signifikan terhadap sikap, nilai, dan perilaku seseorang di tingkat individu dan sosial Pekerja muda religius yang menerapkan nilai-nilai internalisasi agamanya dalam pengelolaan keuangan yang baik (misal menghindari hutang, menjauhi judi, tidak berlebihan dalam belanja, dll), akan menerima manfaat finansial dari perilakunya tersebut. Dengan perilaku keuangan yang bertanggung jawab, mereka akan memiliki kecukupan keuangan sehingga terhindar dari kecemasan keuangan akibat himpitan ekonomi.

Selanjutnya hipotesis kesembilan diperoleh nilai t-statistik sebesar 2,904 lebih besar dari nilai t-tabel (1.960). Diperoleh pula nilai $p$-values sebesar 0,004 atau $\mathrm{p}$ values $<0.050$. Hasil tersebut mengindikasikan bahwa terdapat pengaruh signifikan antara preferensi risiko terhadap personal financial distress melalui perilaku keuangan. Selain itu pada estimasi koefisien jalur, dihasilkan nilai original sample positif sebesar 0,057 yang menandakan bahwa hubungan antara variabel preferensi risiko, perilaku keuangan dan personal financial distress memiliki arah yang positif. Dengan demikian hipotesis H9 diterima, bahwa terdapat pengaruh signifikan positif antara preferensi risiko terhadap personal financial distress melalui perilaku keuangan pada pekerja muda di DKI Jakarta. Penelitian yang dilakukan Keller \& Siegrist (2006) 
Jurnal Riset Manajemen Sains Indonesia (JRMSI) | Vol 11, No. 2, 2020 e-ISSN: 2301-8313 http://doi.org/10.21009/JRMSI

menjelaskan bahwa preferensi risiko memberikan pengaruh terhadap perilaku keuangan aktual mereka, yang pada akhirnya terkait dengan kesejahteraan finansial mereka saat ini. Perbedaan perilaku pengambilan risiko individu akan menyebabkan perilaku keuangan yang berbeda, seperti keputusan investasi yang berbeda (Grable, Britt-Lutter, \& Webb, 2008). Hal ini akan mengakibatkan kepuasan atau ketidakpuasan yang berbeda terhadap situasi keuangan mereka (Mokhtar \& Husniyah, 2017). Kepuasan finansial merupakan komponen dari financial wellbeing (Saurabh \& Nandan, 2018), dan kebalikan dari financial distress.

Hipotesis yang terakhir yaitu kesepuluh diperoleh nilai t-statistik sebesar 9,004 lebih besar dari nilai t-tabel (1.960). Diperoleh pula nilai $p$-values sebesar 0,000 atau p values < 0.050. Hasil tersebut mengindikasikan bahwa terdapat pengaruh signifikan antara locus of cntrol terhadap personal financial distress melalui perilaku keuangan. Selain itu pada estimasi koefisien jalur, dihasilkan nilai original sample negatif sebesar -0,313 yang menandakan bahwa hubungan antara variabel locus of control, perilaku keuangan dan personal financial distress memiliki arah yang negatif. Dengan demikian Hipotesis H10 diterima, bahwa terdapat pengaruh signifikan negatif antara locus of control terhadap personal financial distress melalui perilaku keuangan pada pekerja muda di DKI Jakarta. Bagi para pekerja muda, sangat penting untuk memahami apa yang kebanyakan orang lalui dalam hidup mereka secara efektif untuk 'menangani' semua tekanan kehidupan modern yang kadang-kadang menunjukkan perilaku keuangan yang buruk (Thomas Garman et al. (1996). Hal ini pada akhirnya akan memberdayakan mereka untuk menuju kondisi kesejahteraan finansial yang lebih besar.

\section{KESIMPULAN DAN SARAN}

Berdasarkan hasil analisis data dan pengujian hipotesis dalam penelitian ini maka dapat ditarik beberapa kesimpulan sebagai berikut: 1). Tidak terdapat pengaruh yang signifikan antara Religiusitas terhadap Personal Financial Distress. Tingkat religiusitas yang tinggi tidak serta merta mempengaruhi kesulitan keuangan individu pada tingkat yang sama maupun berbeda, terutama pada kalangan pekerja muda. Walaupun individu menganut agama yang sama, namun tingkat religiusitas mungkin tidak bersifat konstan apalagi jika dihadapkan pada situasi yang penuh tekanan sehingga pengaruhnya sulit diprediksi terhadap personal financial distress. 2). Preferensi risiko berpengaruh signifikan positif terhadap Personal Financial Distress. Preferensi risiko individu yang tinggi berbanding lurus dengan tingkat personal financial distress yang tinggi, dan begitupun sebaliknya, preferensi risiko individu yang rendah berbanding lurus dengan tingkat personal financial distress yang rendah. 3). Locus of control 
Jurnal Riset Manajemen Sains Indonesia (JRMSI) | Vol 11, No. 2, 2020 e-ISSN: 2301-8313 http://doi.org/10.21009/JRMSI

berpengaruh signifikan negatif terhadap Personal Financial Distress. Individu dengan locus of control yang tinggi akan terhindar dari kesulitan keuangan, begitupun sebaliknya individu dengan locus of control yang rendah akan mengalami kesulitan keuangan. 4). Perilaku keuangan berpengaruh signifikan negatif terhadap Personal Financial Distress. Pekerja muda yang mengimplimentasikan dengan baik praktek pengelolaan keuangan pribadinya akan terhindar dari berbagai persoalan keuangan yang dapat memicu timbulnya personal financial distress. 5). Religiusitas berpengaruh signifikan positif terhadap Perilaku keuangan. Semakin tinggi seseorang dalam mengaplikasikan pemahaman agamanya (religiusitas) maka mereka akan semakin baik dalam mengelola keuangan. Begitupun sebaliknya semakin rendah seseorang dalam mengaplikasikan pemahaman agaman (religiusitas) maka mereka akan semakin buruk dalam mengelola keuangan. 6). Preferensi risiko berpengaruh signifikan negatif terhadap perilaku keuangan. Pekerja muda mencari risiko yang tergolong aman dan tidak terlalu rendah dengan tujuan bisa tetap mendapatkan hasil atau keuntungan sesuai harapan, sehingga mereka tetap dapat menerapkan perilaku keuangan yang baik dengan cara mengelola secara maksimal manfaat yang diperoleh dari tingkat risiko yang tidak terlalu rendah. 7). Locus of control berpengaruh signifikan positif terdahap perilaku keuangan. Semakin tinggi locus of control maka akan semakin baik perilaku keuangannya. Begitupun sebaliknya semakin rendah locus of control maka akan semakin buruk perilaku keuangannya. 8). Religiusitas berpengaruh signifikan negatif terhadap personal financial distress melalu perilaku keuangan. Religiusitas yang tinggi akan mengarahkan mereka ke dalam perilaku keuangan positif yang tinggi pula, yang kemudian menurunkan tingkat personal financial distress mereka. Begitupun sebaliknya religiusitas yang rendah akan mengarahkan mereka ke dalam perilaku keuangan positif yang rendah, yang kemudian menaikkan tingkat personal financial distress. 9). Preferensi risiko berpengaruh siginifikan positif terhadap personal financial distess melalui perilaku keuangan. Disaat individu memiliki tingkat pengambilan risiko yang tinggi, maka besar kemungkinan mereka akan mengalami kerugian yang lebih tinggi pula. Sedangkan bagi individu dengan preferensi risiko rendah, mereka akan bertindak atau berperilaku keuangan yang sejalan dengan risiko yang mampu dihadapinya. 10). Locus of control berpengaruh signifikan negatif terhadap personal financial distess melalui perilaku keuangan. Locus of control yang yang tinggi mempengaruhi perilaku keuangan untuk menghasilkan kondisi financial distress serendah mungkin. Begitupun persepsi yang rendah terhadap locus of control individu akan mengarah pada perilaku manajemen keuangan yang kurang baik, dan pada akhirnya akan meningkatkan personal financial distress individu. 
Jurnal Riset Manajemen Sains Indonesia (JRMSI) | Vol 11, No. 2, 2020 e-ISSN: 2301-8313 http://doi.org/10.21009/JRMSI

Adapun saran yang diberikan peneliti agar dapat dijadikan pertimbangan dalam pengembangan ataupun penyempurnaan penelitian selanjutnya antara lain adalah: Penelitian selanjutnya harus mempertimbangkan potensi lain penentu yang dapat meningkatkan religiusitas, preferensi risiko, locus of control dan perilaku keuangan generasi milenial di Indonesia sehingga mereka dapat menghadapi kesulitan keuangan dengan cara yang lebih bijaksana dan matang. Selain itu, penelitian selanjutnya agar dapat memodifikasi model penelitian dengan menambah variabel lain sebagai variabel independen ataupun variabel intervening yang berkorelasi dengan personal financial distress seperti financial literacy. Penelitian selanjutnya juga dapat memperluas subjek penelitian yang mencakup keseluruhan populasi di Indonesia, tidak terbatas hanya pada pekerja muda saja, sehingga hasil penelitian dapat lebih tergeneralisir. Penelitian selanjutnya juga dapat mempertimbangkan menggunakan teknik analisis data lainnya seperti analisis regresi atau mencoba pendekatan kualitiatif dalam menginvestigasi personal financial distress.

\section{DAFTAR PUSTAKA}

Alifiah, M. N. (2014). Prediction of Financial Distress Companies in the Trading and Services Sector in Malaysia Using Macroeconomic Variables. Procedia - Social and Behavioral Sciences, 129, 90-98.

Archuleta, K. L., Dale, A., \& Spann, S. M. (2013). College Students and Financial Distress: Exploring Debt, Financial Satisfaction, and Financial Anxiety. Journal of Financial Counseling and Planning, 24(2), 50-62.

Arifin, A. Z. (2018). Influence of financial attitude, financial behavior, financial capability on financial satisfaction. Advances in Social Science, Education and Humanities Research (ASSEHR), 186, 100-103. https://doi.org/10.2991/insyma-18.2018.25

Bagwell, Dorothy C. Kim, J. (2003). Financial Stress, Health Status, and Absenteesim in Credit Counseling Clients. The Journal of Consumer Education, 21.

Bank Indonesia. (2020). Survei Konsumen Januari 2020.

Barton, A. W., Futris, T. G., \& Nielsen, R. B. (2015). Linking financial distress to marital quality: The intermediary roles of demand/withdraw and spousal gratitude expressions. Personal Relationships, 22(3), 536-549. https://doi.org/10.1111/pere.12094

Capuano, A., \& Ramsay, I. (2011). What Causes Suboptimal Financial Behaviour? An Exploration of Financial Literacy, Social Influences and Behavioural Economics. $U$ of Melbourne Legal Studies Research Paper, (540). https://doi.org/10.2139/ssrn.1793502

Cobb-Clark, D. A., Kassenboehmer, S. C., \& Sinning, M. G. (2016). Locus of control and savings. Journal of Banking and Finance, 73(7837), 113-130. https://doi.org/10.1016/j.jbankfin.2016.06.013

Dalton, P. S., Nhung, N., \& Rüschenpöhler, J. (2019). Worries of the poor: The impact of financial burden on the risk attitudes of micro-entrepreneurs. Journal of Economic Psychology, (August), 102198. https://doi.org/10.1016/j.joep.2019.102198

Dessart, A. M., \& Kuylen, A. A. (1986). The nature, extent, cause and consequence of problematic debt situations. Journal of Consumer Policy, 9(3), 311-334.

Dewi, A. P. (2013). Rata-rata orang Indonesia menabung Rp355 ribu per bulan. 
Jurnal Riset Manajemen Sains Indonesia (JRMSI) | Vol 11, No. 2, 2020 e-ISSN: 2301-8313 http://doi.org/10.21009/JRMSI

Drentea, P, \& Lavrakas, P. J. (2000). Over the limit: the association among health, race and debt. Social Science \& Medicine (1982), 50(4), 517-529. Retrieved from http://www.ncbi.nlm.nih.gov/pubmed/10641804

Drentea, Patricia. (2000). Age, debt and anxiety. Journal of Health and Social Behavior, 41(4), 437-450. https://doi.org/10.2307/2676296

Eckel, C. C. (2019). Measuring individual risk preferences. IZA World of Labor, 454.

Garman, E. T., Sorhaindo, B., Kim, J., Xiao, J. J., Bailey, W., \& Prawitz, A. D. (2004). The Development of the Beta Version of the InCharge Financial Distress Scale. Consumer Interests Annual, 50.

Garman, E. T., Sorhaindo, B., Prawitz, A. D., O’Neill, B., Osteen, S., Kim, J., ... Weisman, R. L. (2005). Development of and Norms for the InCharge Financial Distress/Financial WellBeing Scale: A Summary. Consumer Interest Annual, 51, 1-6.

Ghozali, I. (2016). Aplikasi Analisis Multivariate Dengan Program IBM SPSS 23 (VIII). Semarang: BPFE Universitas Diponegoro.

Grable, J., Britt-Lutter, S., \& Webb, F. (2008). Environmental and Biopsychosocial Profiling as a Means for Describing Financial Risk-Taking Behavior. Journal of Financial Counseling and Planning, 19(2).

Graham, L., Jordan, L., Hutchinson, A., \& de Wet, N. (2018). Risky behaviour: a new framework for understanding why young people take risks. Journal of Youth Studies, 21(3), 324-339. https://doi.org/10.1080/13676261.2017.1380301

Hayhoe, C. R., Leach, L. J., Turner, P. R., Bruin, M. J., \& Lawrence, F. C. (2000). Differences in spending habits and credit use of college students. Journal of Consumer Affairs, 34(1), 113-133. https://doi.org/10.1111/j.1745-6606.2000.tb00087.x

Hertwig, R., Wulff, D. U., \& Mata, R. (2018). Three gaps and what they may mean for risk preference. Philosophical Transactions of the Royal Society of London. Series B, Biological Sciences, 374(1766). https://doi.org/10.1098/rstb.2018.0140

Hess, D. (2012). The impact of religiosity on personal financial decisions. 14, 1-13.

Hsee, C., \& Weber, E. (1998). Cross-cultural Differences in Risk Perception, but Cross-cultural Similarities in Attitudes Towards Perceived Risk. Management Science, 44(9), 1205 1217.

Iddagoda, Y. A., \& Opatha, H. H. D. N. P. (2017). Religiosity: Towards A Conceptualization and An Operationalization. Sri Lankan Journal of Human Resource Management, 7(1), 59. https://doi.org/10.4038/sljhrm.v7i1.5637

Jacobson, B. H., Aldana, S. G., Goetzel, R. Z., Vardell, K. D., Adams, T. B., \& Pietras, R. J. (1996). The relationship between perceived stress and self-reported illness- related absenteeism. American Journal of Health Promotion, 11(1), 54-61. https://doi.org/10.4278/0890-1171-11.1.54

Keller, C., \& Siegrist, M. (2006). Money Attitude Typology and Stock Investment. The Journal of Behavioral Finance, 7, 88-96. https://doi.org/10.1207/s15427579jpfm0702

Kholilah, N. Al, \& Iramani, R. (2013). Studi Financial Management Behavior Pada Masyarakat Surabaya. Journal of Business and Banking, 3(1), 69. https://doi.org/10.14414/jbb.v3i1.255

Krause, N., Jay, G., \& Liang, J. (1991). Financial strain and psychological well-being among the American and Japanese Elderly. Psychology and Aging, 6(2), 170-181. https://doi.org/10.1037/0882-7974.6.2.170

Lajuni, N., Bujang, I., \& Aziz Karia, A. (2018). The Effect of Religiosity, Financial Knowledge, and Financial Behaviour on Financial Distress Among Undergraduate Students. Proceedings of the 2nd Advances in Business Research International Conference, 179-186. https://doi.org/10.1007/978-981-10-6053-3_17 
Jurnal Riset Manajemen Sains Indonesia (JRMSI) | Vol 11, No. 2, 2020 e-ISSN: 2301-8313 http://doi.org/10.21009/JRMSI

Lajuni, N., Bujang, I., Karia, A. A., \& Yacob, Y. (2018). Religiosity, Financial Knowledge, and Financial Behavior Influence on Personal Financial Distress Among Millennial Generation. Jurnal Manajemen Dan Kewirausahaan, 20(2), 92-98. https://doi.org/10.9744/jmk.20.2.92-98

LeBaron, A., Kelley, H., Hill, E. J., \& Galbraith, Q. (2019). Finances, religion, and the FAAR model: How religion exacerbates and alleviates financial stress. Psychology of Religion and Spirituality.

León, A. K., \& Pfeifer, C. (2017). Religious activity, risk-taking preferences and financial behaviour: Empirical evidence from German survey data. Journal of Behavioral and Experimental Economics , 69, 99-107. https://doi.org/10.1016/j.socec.2017.05.005

Marlina, L., Irawati, N., Sadalia, I., \& Muda, I. (2019). The financial behavior traits impact on financial distress at small medium enterprise's (the relationships between the industry and sustainable development in indonesia). International Journal of Scientific and Technology Research, 8(4), 27-30.

Marsh, B. A. (2006). Examining the personal finanial attitudes, behavior and knowledge levels of first-year and senior students at Baptist Universities in the State of Texas. Bowling Green State University Political Science.

Mata, R., Frey, R., Richter, D., Schupp, J., \& Hertwig, R. (2018). Risk preference: A view from psychology. Journal of Economic Perspectives, 32(2), 155-172. https://doi.org/10.1257/jep.32.2.155

Mills, R. J., Grasmick, H. G., Morgan, C. S., \& Wenk, D. (1992). The Effects of Gender, Family Satisfaction, and Economic Strain on Psychological Well-Being. Family Relations, 41(4), 440. https://doi.org/10.2307/585588

Mokhtar, N., \& Husniyah, A. R. (2017). Determinants of financial well-being among public employees in Putrajaya, Malaysia. Pertanika Journal of Social Sciences and Humanities, 25(3), 1241-1260.

Nofsinger, J. R. (2003). Investment blunders (of the rich and famous) ... and what you can learn from them. In Choice Reviews Online (Vol. 40). https://doi.org/10.5860/choice.40-4119

O’Neill, B., Sorhaindo, B., Prawitz, A. D., Kim, J., \& Garman, E. T. (2006). Financial Distress: Definition, Effects, and Measurement. Consumer Interests Annual, 52, 1-8.

Onyima, J. K., \& Nkechi, O. C. (2017). Religiosity and Financial Decisions of Young Adult Nigerians: Is the Financial Advice of religious leaders Sacrosanct? Journal of Economics and Sustainable Development, 8(8), 84-92.

Özmete, E. (2015). Measuring the Poverty of Elderly People with Needs Analysis in Turkey. In Handbook of Research on Behavioral Finance and Investment Strategies: Decision Making in the Financial Industry (pp. 127-146). https://doi.org/10.4018/978-1-46667484-4.ch008

Patten, D. M. (2005). An analysis of the impact of locus-of-control on internal auditor job performance and satisfaction. Managerial Auditing Journal, 20(9), 1016-1029.

Perry, V. G., \& Morris, M. D. (2005). Who is in control? The role of self perception, knowledge, and income in explaining consumer financial behavior. The Journal of Consumer Affairs, 39(2), 299-313.

Prawitz, A. D., Garman, E. T., Sorhaindo, B., Neill, B. O., Kim, J., \& Drentea, P. (2006). InCharge Financial Distress/Financial Well-Being Scale: Development, Administration, and Score Interpretation. Journal of Financial Counseling and Planning, 17(1), 34-50. https://doi.org/10.1037/t60365-000

Rika, H. (2019). Total Pinjaman Online Tembus Rp41,04 Triliun per Mei 2019. Retrieved October 4, 2019, from CNN Indonesia website: https://www.cnnindonesia.com/ekonomi/20190627200551-78-407152/total-pinjaman- 
Jurnal Riset Manajemen Sains Indonesia (JRMSI) | Vol 11, No. 2, 2020 e-ISSN: 2301-8313 http://doi.org/10.21009/JRMSI

online-tembus-rp4104-triliun-per-mei-2019

Rotter, J. B. (1966). Generalized Expenctancies for Internal Versus External Control of Reinforcement. Psychological Moonographs: General and Applied, 80(1), 1-28.

Saji, T. G. (2018). Financial Distress and Stock Market Failures: Lessons from Indian Realty Sector. The Journal of Business Perspective, 22(1), 50-60. https://doi.org/10.1177/0972262917750244

Saurabh, K., \& Nandan, T. (2018). Role of financial risk attitude and financial behavior as mediators in financial satisfaction: Empirical evidence from India. South Asian Journal of Business Studies, 7(2), 207-224. https://doi.org/10.1108/SAJBS-07-2017-0088

Sedikides, C. (2010). Why Does Religiosity Persist? Personality and Social Psychology Review, 14(1), 3-6.

Shweder, R. A. (1991). Thinking through cultures: Expeditions in cultural psychology. Cambridge: Harvard University Press.

Sipon, S., Othman, K., Ghani, Z. A., \& Radzi, H. M. (2014). The Impact of Religiosity on Financial Debt and Debt Stress. Procedia - Social and Behavioral Sciences, 140(2003), 300-306. https://doi.org/10.1016/j.sbspro.2014.04.424

Stamp, S. (2009). An Exploratory Analysis of Financial Difficulties among Those Living Below the Poverty Line in Ireland. Combat Poverty Agency Working Paper Series, 9(2), 1-92. https://doi.org/10.13140/RG.2.2.29113.06248

Thomas Garman, E., Leech, I. E., \& Grable, J. E. (1996). The negative impact of employee poor personal financial behaviors on employers. Journal of Financial Counseling and Planning, 7(540), 157-168.

Vermeer, A. B. L., \& Sanfey, A. G. (2015). The Effect of Positive and Negative Feedback on Risk-Taking across Different Contexts. PLoS ONE, 10(9), 1-13.

Ware, S. J. (2015). Debt, Poverty, and Personal "Financial Distress." American Bankruptcy Law Journal, 89(3), 493-510.

Wen, F., He, Z., \& Chen, X. (2014). Investors' risk preference characteristics and conditional skewness. Mathematical Problems in Engineering, 2014, 1-14. https://doi.org/10.1155/2014/814965

Xiao, J. J. (2009). Applying behavior theories to financial behavior. Handbook of Consumer Finance and Research, 69-81.

Xu, Y., Beller, A. H., Roberts, B. W., \& Brown, J. R. (2015). Personality and young adult financial distress. Journal of Economic Psychology, 51, 90-100. https://doi.org/10.1016/j.joep.2015.08.010

Yu, K. F., \& Jupri, N. (2015). Factors That Lead To Financial Distress of Generation Y in Malaysia. International Journal of Accounting and Business Management, 3(2), 109-120. https://doi.org/10.24924/ijabm/2015.11/v3.iss2/109.120

Ziemkiewicz, C., Crouser, R. J., Yauilla, A. R., Su, S. L., Ribarsky, W., \& Chang, R. (2011). How locus of control influences compatibility with visualization style. VAST 2011 - IEEE Conference on Visual Analytics Science and Technology 2011, Proceedings, 81-90. https://doi.org/10.1109/VAST.2011.6102445 